\title{
Step-by-step towards a better understanding of health behaviour
}

Citation for published version (APA):

Kasten, S. (2019). Step-by-step towards a better understanding of health behaviour. [Doctoral Thesis, Maastricht University]. ProefschriftMaken Maastricht. https://doi.org/10.26481/dis.20191002sk

Document status and date:

Published: 01/01/2019

DOI:

10.26481/dis.20191002sk

Document Version:

Publisher's PDF, also known as Version of record

\section{Please check the document version of this publication:}

- A submitted manuscript is the version of the article upon submission and before peer-review. There can be important differences between the submitted version and the official published version of record.

People interested in the research are advised to contact the author for the final version of the publication, or visit the DOI to the publisher's website.

- The final author version and the galley proof are versions of the publication after peer review.

- The final published version features the final layout of the paper including the volume, issue and page numbers.

Link to publication

\footnotetext{
General rights rights.

- You may freely distribute the URL identifying the publication in the public portal. please follow below link for the End User Agreement:

www.umlib.nl/taverne-license

Take down policy

If you believe that this document breaches copyright please contact us at:

repository@maastrichtuniversity.nl

providing details and we will investigate your claim.
}

Copyright and moral rights for the publications made accessible in the public portal are retained by the authors and/or other copyright owners and it is a condition of accessing publications that users recognise and abide by the legal requirements associated with these

- Users may download and print one copy of any publication from the public portal for the purpose of private study or research.

- You may not further distribute the material or use it for any profit-making activity or commercial gain

If the publication is distributed under the terms of Article $25 \mathrm{fa}$ of the Dutch Copyright Act, indicated by the "Taverne" license above, 
Summary 


\section{Summary}

Over the last decades the incidence of non-communicable diseases (NCDs) such as cancer, heart disease, and diabetes has been growing, causing about $70 \%$ of deaths world-wide. Tobacco use, an unhealthy diet, physical inactivity, and alcohol consumption have been identified as major risk factors for NCDs. Preventing and changing these health behaviours therefore has become one of the main focuses of public health organisations around the globe. However, to be able to change health behaviours it is important to understand what causes the behaviour in the first place. Various socio-cognitive theories and models have been introduced to conceptualize determinants of health behaviours.

While many of these theories have been widely used to explain behaviour or to serve as theoretical basis for interventions, they have also been criticised. A prominent criticism of many models pertains to their focus on motivational factors and intention. Although both motivation and intention have shown to be of importance when it comes to understanding and predicting health behaviour change, they only account for about $30 \%$ of explained variance. Criticism towards this motivational and intentional focus has been two-fold. One the one hand, these models do not clarify how motivation is formed and what factors precede the socalled motivational phase. On the other hand, while intention seems to be a proximate factor to behaviour, people often fail to actually translate their intentions into behaviour, a phenomenon known as the intention-behaviour gap. More research therefore needs to focus on the processes that translate a person's intention into behaviour.

Previous research has made efforts to compare and combine models to construct integrated approaches to understand health behaviour. One of these integrated models, the I-Change Model, will serve as theoretical basis for this thesis. This thesis aims to reach better comprehension of complex health behaviours by testing the I- 
Change Model and some of its assumptions and by integrating new concepts and conceptual explanatory pathways, where needed.

Chapter 1 describes the background of this thesis and provides a rational for a theory-based approach to the investigation of health behavior. Furthermore, the chapter gives a detailed description of the I-Change Model and discusses the strengths and pitfalls of the model. Finally, the chapter introduces the three aims of the thesis and gives an overview of the research questions that are investigated throughout the following chapters.

Chapter 2 presents the results of a longitudinal study on the efficacy, use and usability of two versions of a web-based computer-tailored intervention for physical activity. The study compared an eHealth and a mHealth version of an intervention to a control group. Regression analysis revealed a significant difference between the intervention group (i.e. eHealth and mHealth) and the control group, indicating that the intervention itself was effective in increasing physical activity among the adult population. A small borderline significant effect was found when comparing the eHealth version with the control group, but no effect was found for mHealth vs. control.

With regard to the use and usability, the results indicated that the dropout rate was lowest in the eHealth condition and that participants rated the eHealth version significantly better with regard to usability and appreciation. These results suggest that the eHealth version might be slightly more suitable to increase physical activity than the mHealth version with regard to use and usability.

Chapter 3 provides results of an observational survey study regarding physical activity. The study aimed to test whether the effect of pre-motivational factors (i.e. knowledge, risk perception, cues, and cognizance) on intention and behaviour were mediated by motivational factors (i.e. attitudes, social influence, and self-efficacy). 
To test this assumption five different structural equation models were investigated. Model 1 to 4 tested the effect of each pre-motivational factor on motivation and behaviour separately, while model 5 tested the effect of all four proposed premotivational factors simultaneously. The results indicated that the association of risk perception, cues, and cognizance on intention and behaviour were fully mediated by motivation factors when tested separately. However, when all factors were included in one model, only the effect of cognizance on motivational factors remained. These results show that the assumption of the I-Change Model, that the effect of premotivational factors on behaviour is mediated by motivational factors, was supported by our findings. Additionally, the results underline the importance of cognizance as an additional factor within the model.

Chapter 4 describes the results of a detailed investigation of the cognizance concept with regard to physical activity and sedentary behaviour. The study investigated two proposed components of cognizance: behavioural cognizance and criterion cognizance. Behavioural cognizance refers to the degree that the self-estimation of a person's behaviour is in line with actual behaviour, whereas criterion cognizance pertains to the level of awareness of a person with regard to the healthiness of the behaviour. Based on participants' scores on both components they were classified as either positively cognizant (e.g. correctly estimating one's behaviour as healthy), negatively cognizant (e.g. correctly estimating one's behaviour as unhealthy), or noncognizant (e.g. not correctly estimating one's behaviour as (un)healthy). The results of the study indicate that $78 \%$ and $41 \%$ of the participants were considered noncognizant regarding their sedentary behaviour and physical activity respectively. Regarding sedentary behaviour, the majority respondents were characterized as non-cognizant due to a lack of criterion cognizance, while with regard to physical activity people mostly lacked behavioural cognizance. When the groups (i.e. noncognizant vs. positive cognizant (physical activity), non-cognizant vs. negative cognizant (sedentary behaviour)) were compared to each other with regard to 
motivational factors, the results indicated that being cognizant resulted in a higher intention, attitude, self-efficacy, more perceived modelling and more specific action plans regarding physical activity. However, regarding sedentary behaviour no such differences were detected.

Chapter 5 provides insight into the role of plan enactment within the transition of planning to behaviour. The results indicate that the effect of planning (e.g. putting out a fruit basket, or taking fruit to work) on fruit consumption is fully mediated by plan enactment. Additionally, the study shows that the effect of planning on enactment is moderated by habit strength, self-efficacy, and intention, indicating that plans are more often enacted when participants show high levels of intention, self-efficacy and a healthy habit, but that an opposing habit can hinder the transition from plans to enactment. Therefore, results show that plan enactment plays an important role within the planning process and suggest that factors that facilitate or hinder the enactment of plans need to be considered during development of health behaviour (or behaviour change) interventions.

Chapter 6 replicates the mediating effect of plan enactment between planning and behaviour found in Chapter 5 with regard to physical activity. Additionally, the study investigates the role of self-efficacy within the planning-plan enactment-behaviour process. The results indicate that self-efficacy significantly predicted planning, plan enactment, and behaviour. Furthermore, the results showed that the enactment of plans increased self-efficacy, but that planning without enactment could even lead to a negative effect on self-efficacy. Making plans might therefore be unproductive or even counterproductive if the plans are not enacted correctly. However, if plans (e.g. buying new sports shoes) are enacted they can lead to an increase of selfefficacy regarding the goal outcome (i.e. being physically active). This indicates that plan enactment plays a central role with regard to physical activity and that the enactment of plans can be helpful to enhance self-efficacy. 
Chapter 7 presents a summary of the main findings of this dissertation. Furthermore, the chapter discusses questions that remain unanswered and gives implications for future research. Finally, the chapter closes with a critical view on existing integrative models and discusses possible ways forward to further increase our understanding of health behaviour. 
Samenvatting 


\section{Samenvatting}

Tijdens de laatste decennia is het aantal niet-overdraagbare ziekten (engels: noncommunicable diseases, NCD's) zoals kanker, hart- en vaatziekten en diabetes toegenomen, wat wereldwijd ongeveer $70 \%$ van de sterfgevallen veroorzaakt. Tabaksgebruik, ongezonde voeding, gebrek aan lichaamsbeweging en alcoholgebruik blijken belangrijke risicofactoren voor NCD's te zijn. Het voorkomen en veranderen van dit gezondheidsgedrag is daarom een van de belangrijkste aandachtspunten geworden van volksgezondheidsorganisaties over de hele wereld. Om het gezondheidsgedrag te kunnen veranderen is het echter belangrijk om te begrijpen wat de oorzaken van het gedrag zijn. Verschillende sociaal-cognitieve theorieën en modellen zijn geïntroduceerd om determinanten van gezondheidsgedrag te conceptualiseren.

Veel van deze theorieën zijn op grote schaal gebruikt om gedrag te verklaren of als theoretische basis voor interventies, maar er is ook kritiek geuit op deze theorieën en modellen. Een belangrijk kritiekpunt is de focus van theorieën en modellen op motivatiefactoren en intentie. Hoewel zowel motivatie als intentie van belang zijn gebleken voor het begrijpen en voorspellen van veranderingen in gezondheidsgedrag, zijn ze slechts verantwoordelijk voor ongeveer $30 \%$ van de verklaarde variantie. De kritiek op de focus op motivatie en intentie is tweeledig. Enerzijds verduidelijken deze modellen niet hoe de motivatie wordt gevormd en welke factoren voorafgaan aan de zogenaamde motivatiefase. Aan de andere kant, lukt het veel mensen vaak niet om hun intenties daadwerkelijk te vertalen naar gedrag, een fenomeen dat bekend staat als de intentie-gedragskloof. Meer onderzoek moet zich daarom richten op de processen die de intentie van een persoon vertalen naar gedrag.

Eerder onderzoek heeft getracht modellen te vergelijken en te combineren om geïntegreerde benaderingen te construeren voor het begrijpen van gezondheidsgedrag. Eén van deze geïntegreerde modellen, het I-Change Model, zal 
als theoretische basis dienen voor deze dissertatie. Dit proefschrift beoogt een beter begrip te krijgen van complex gezondheidsgedrag door het I-Change Model en enkele van zijn aannames te testen en door nieuwe concepten en conceptuele verklarende paden te integreren, waar nodig.

Hoofdstuk 1 beschrijft de achtergrond van dit proefschrift en geeft een rationele benadering voor het theoretisch kader van het onderzoek naar gezondheidsgedrag. Verder geeft het hoofdstuk een gedetailleerde beschrijving van het I-Change Model en bespreekt de sterke en zwakke punten van het model. Tot slot introduceert het hoofdstuk de drie doelstellingen van het proefschrift en geeft een overzicht van de onderzoeksvragen die in de volgende hoofdstukken worden onderzocht.

Hoofdstuk 2 presenteert de resultaten van een longitudinaal onderzoek naar de effectiviteit, het gebruik en de bruikbaarheid van twee versies van een webbased computer-tailored interventie voor lichaamsbeweging. De studie vergeleek een eHealth en een mHealth versie van een interventie met een controlegroep. Uit de regressieanalyse bleek er een significant verschil te zijn tussen de interventiegroep (d.w.z. eHealth en mHealth) en de controlegroep. Dit wijst erop dat de interventie effectief was in het verhogen van de lichamelijke activiteit van de volwassen bevolking. Bij vergelijking van de eHealth-versie met de controlegroep werd een marginaal-significant effect gevonden, maar er werd geen effect gevonden tussen de mHealth interventie versus de controlegroep. Wat betreft het gebruik en de bruikbaarheid bleek uit de resultaten dat het uitvalpercentage het laagst was in de eHealth conditie en dat de deelnemers de bruikbaarheid van de eHealth versie significant beter beoordeelden en een hogere waardering gaven. Deze resultaten suggereren dat de eHealth versie wellicht geschikter is om de fysieke activiteit te verhogen dan de mHealth versie wat betreft het gebruik en de bruikbaarheid. 
Hoofdstuk 3 beschrijft de resultaten van een observatiestudie over lichaamsbeweging. Het onderzoek was erop gericht om te testen of het effect van pre-motiverende factoren (d.w.z. kennis, risicoperceptie, cues en cognitie) op intentie en gedrag werd gemedieerd door motiverende factoren (d.w.z. houding, sociale invloed en zelfredzaamheid). Om deze aanname te testen werden vijf verschillende structurele vergelijkingsmodellen onderzocht. Model 1 tot 4 testte het effect van elke pre-motiverende factor op motivatie en gedrag afzonderlijk, terwijl model 5 het effect van alle vier voorgestelde pre-motiverende factoren tegelijkertijd testte. De resultaten gaven aan dat de associatie van risicoperceptie, cues en cognizatie op intentie en gedrag volledig werd gemedieerd door motivatiefactoren wanneer deze afzonderlijk werden getest. Echter, wanneer alle factoren in één model werden opgenomen, bleef alleen het effect van cognizance op motivatiefactoren over. Deze resultaten tonen aan dat de veronderstelling van het I-Change Model, dat het effect van pre-motiverende factoren op het gedrag wordt gemedieerd door motiverende factoren, word ondersteund door onze bevindingen. Daarnaast onderstrepen de resultaten het belang van cognizantie als extra factor binnen het model.

Hoofdstuk 4 beschrijft de resultaten van een gedetailleerd onderzoek naar het cognizance concept met betrekking tot lichaamsbeweging en sedentair gedrag. In het onderzoek zijn twee voorgestelde componenten van cognizance onderzocht: gedragscognizance en criteriumcognizance. Gedragscognizantie verwijst naar de mate waarin de zelfwaardering van iemands gedrag in overeenstemming is met het feitelijke gedrag, terwijl criteriumcognizance betrekking heeft op het bewustzijnsniveau van een persoon ten aanzien van de gezondheid van het gedrag. Op basis van de scores van de deelnemers op beide componenten werden ze geclassificeerd als ofwel positief cognitief (bv. correct inschatten van het eigen gedrag als gezond), negatief cognitief (bv. correct inschatten van het eigen gedrag als ongezond), of niet-cognitief (bv. niet correct inschatten van het eigen gedrag als 
(on)gezond). De resultaten van het onderzoek geven aan dat $78 \%$ en $41 \%$ van de deelnemers als niet-cognizant werden beschouwd met betrekking tot respectievelijk hun zittend gedrag en hun lichaamsbeweging. Met betrekking tot sedentair gedrag werd de meerderheid van de respondenten gekarakteriseerd als niet-cognizant door een gebrek aan criteriumkennis, terwijl het bij lichamelijke activiteit vooral ontbrak aan gedragskennis. Wanneer de groepen (d.w.z. niet-cognizant versus positief cognizant (lichaamsbeweging), niet-cognizant versus negatief cognizant (sedentair gedrag)) met elkaar werden vergeleken ten aanzien van motiverende factoren, gaven de resultaten aan dat cognizant zijn resulteerde in een hogere intentie, attitude, zelfeffectiviteit, meer waargenomen modellering en specifiekere actieplannen met betrekking tot fysieke activiteit. Met betrekking tot sedentair gedrag werden dergelijke verschillen echter niet geconstateerd.

Hoofdstuk 5 geeft inzicht in de rol van planvorming binnen de overgang van planning naar gedrag. De resultaten geven aan dat het effect van planning (bv. het klaar leggen van een fruitmand, of het meenemen van fruit naar het werk) op de fruitconsumptie volledig wordt gemedieerd door het uitvoeren van plannen. Daarnaast toont het onderzoek aan dat het effect van planning op de uitvoering gemodereerd wordt door de mate van de gewoonte, de zelfredzaamheid en de intentie. Dit wijst erop dat plannen vaker worden uitgevoerd wanneer de deelnemers een hoog niveau van intentie, zelfredzaamheid en een gezonde gewoonte tonen, maar dat een tegenovergestelde gewoonte de overgang van plannen naar uitvoering kan belemmeren. De resultaten tonen dan ook aan dat planvorming een belangrijke rol speelt binnen het planningsproces en suggereren dat factoren die de uitvoering van plannen faciliteren of hinderen bij de ontwikkeling van gezondheidsinterventies in overweging moeten worden genomen.

In hoofdstuk 6 wordt het mediërende effect van de planvorming tussen planning en gedrag uit hoofdstuk 5 met betrekking tot lichaamsbeweging herhaald. 
Daarnaast onderzoekt de studie de rol van zelfeffectiviteit binnen het plannings-, gedrags- en uitvoeringsproces. De resultaten geven aan dat zelfredzaamheid een significante voorspelling is van planning, planvorming en gedrag. Verder toonden de resultaten aan dat het uitvoeren van plannen de zelfeffectiviteit doen toenemen, maar dat planning zonder uitvoering zelfs kan leiden tot een negatief effect op de zelfeffectiviteit. Het maken van plannen kan daarom onproductief of zelfs contraproductief zijn als de plannen niet correct worden uitgevoerd. Echter, als plannen (bijvoorbeeld het kopen van nieuwe sportschoenen) worden uitgevoerd, kunnen ze leiden tot een toename van de zelfredzaamheid met betrekking tot het beoogde resultaat (d.w.z. fysiek actief zijn). Dit geeft aan dat de uitvoering van het plan een centrale rol speelt met betrekking tot fysieke activiteit en dat de uitvoering van de plannen nuttig kan zijn om de zelfredzaamheid te verbeteren.

Hoofdstuk 7 geeft een samenvatting van de belangrijkste bevindingen van dit proefschrift. Verder gaat het hoofdstuk in op vragen die onbeantwoord blijven en geeft het aanbevelingenvoor toekomstig onderzoek. Tot slot sluit het hoofdstuk af met een kritische blik op bestaande integratieve modellen en bespreekt het mogelijke manieren om ons begrip van gezondheidsgedrag verder te vergroten. 